Article

\title{
Daily Mobility Patterns: Reducing or Reproducing Inequalities and Segregation?
}

\author{
Lina Hedman ${ }^{1, *}$, Kati Kadarik ${ }^{2}$, Roger Andersson ${ }^{2}$ and John Östh ${ }^{2,3}$ \\ ${ }^{1}$ Centre for Research and Development, Uppsala University/Region Gävleborg, 80188 Gävle, Sweden; \\ E-Mail: lina.hedman@regiongavleborg.se \\ 2 Institute for Housing and Urban Research, Uppsala University, 75120 Uppsala, Sweden; \\ E-Mails: kati.kadarik@ibf.uu.se (K.K.), roger.andersson@ibf.uu.se (R.A.) \\ ${ }^{3}$ Department of Social and Economic Geography, Uppsala University, 75105 Uppsala, Sweden; \\ E-Mail: john.osth@kultgeog.uu.se \\ * Corresponding author
}

Submitted: 15 November 2020 | Accepted: 8 February 2021 | Published: 13 May 2021

\begin{abstract}
Theory states that residential segregation may have a strong impact on people's life opportunities. It is unclear, however, to what extent the residential environment is a good representation of overall exposure to different people and environments. Daily mobility could reduce the negative effects of segregation if people change environments and/or become more mixed. They could also enhance existing segregation patterns if daily mobility produces more segregated environments. This article uses mobile phone data to track daily mobility patterns with regard to residential segregation. We test the extent to which patterns differ between residents in immigrant-dense areas and those from areas with a greater proportion of natives. Results suggest, in line with previous research, that daily mobility patterns are strongly segregated. Phones originating from more immigrant-dense areas are more likely to (1) remain in the home area and (2) move towards other immigrant-dense areas. Hence, although mobility does mitigate segregation to some extent, most people are mainly exposed to people and neighbourhoods who live in similar segregated environments. These findings are especially interesting given the case study areas: two medium-sized Swedish regions with relatively low levels of segregation and inequality and short journey distances.
\end{abstract}

\section{Keywords}

daily mobility; mobile phone data; residential environment; segregation; Sweden

\section{Issue}

This article is part of the issue "Vicious Circle of Segregation: Understanding the Connectedness of Spatial Inequality across Generations and Life Domains" edited by Tiit Tammaru (University of Tartu, Estonia), Siiri Silm (University of Tartu, Estonia), Frank Witlox (Ghent University, Belgium), Maarten van Ham (Delft University of Technology, The Netherlands) and Madli-Johanna Maidla (University of Tartu, Estonia).

(C) 2021 by the authors; licensee Cogitatio (Lisbon, Portugal). This article is licensed under a Creative Commons Attribution 4.0 International License (CC BY).

\section{Introduction}

Residential segregation is one of the major urban problems in contemporary Sweden, judging by the attention and number of recent publications by media, government, and academia. Internationally too, the interest in segregation is expanding. As Musterd (2020) points out, summing up his edited handbook on urban segre- gation, this increasing interest is closely related to urban problems emerging during a period of intensified globalization where socioeconomic polarization has grown at the same time as nation states and cities have favoured neoliberal planning and policies. Most of the literature acknowledges that spatial segregation is part and parcel of the production and reproduction of inequality, affecting socialization processes and shaping conditions for 
people's opportunities in life. The growing interest in studying the effects of segregation, often by addressing the issue of neighbourhood effects (Sampson, 2012), has further contributed to strengthening the emphasis on process, dynamics, and how individuals and groups of individuals over long periods of time are affected by their place of residence.

Not least, in relation to the challenges of measuring neighbourhood effects, the issue of spatial scale emerges as a key aspect (R. Andersson, \& Musterd, 2010; Kadarik, Miltenburg, Musterd, \& Östh, 2021). As argued by Östh and Türk (2020; see also Grannis, 1998, 2005; Kasarda \& Janowitz, 1974), this points in the direction of knowing more, not only about where people reside but also about how infrastructure and accessibility shape a neighbourhood's conditions for its residents. Related methodological problems when estimating neighbourhood effects are those of timing and duration of exposure (Galster, Andersson, \& Musterd, 2016; Musterd, Galster, \& Andersson, 2012). These challenges are often discussed in relation to the life course but are just as relevant on a day-to-day basis (Kwan, 2012; Park \& Kwan, 2018). People do not limit their lives to their home neighbourhood but move around in space, experiencing many different environments over the course of a day. Most studies estimating neighbourhood effects ignore daily mobility, implicitly assuming that a neighbourhood's relative location, population composition, and social status reflect its residents' overall exposure to different domains. Previous research has demonstrated that this is erroneous: Residential patterns are rather poor proxies for people's full exposure to different environments and population groups (Browning \& Soller, 2014; Jones \& Pebley, 2014). Consequently, estimates of neighbourhood effects may turn out to be biased. Uncertainty about actual exposure and a failure to take it into account-the 'uncertain geographic context problem' (Kwan, 2012)-is, according to Park and Kwan (2018), one of the most serious challenges facing neighbourhood effect research. It is especially problematic in relation to those living in the bottom-end of the neighbourhood hierarchy. They are generally assumed to face the most serious negative consequences of segregation and are the target of most anti-segregation initiatives yet their exposure to deprivation risks being exaggerated if their daily exposure to more resourceful areas is not accounted for (Jones \& Pebley, 2014; Kwan, 2018; Tan, Kwan, \& Chen, 2020).

The work of Y. M. Park, M. P. Kwan and others (apart from those mentioned above; see, e.g., van Ham \& Tammaru, 2016; Wong \& Shaw, 2011) stress the importance of analysing segregation from a mobility perspective. People's daily travels in and out of neighbourhoods of different composition and characteristics, as well as their length of exposure to different environments, need to be better understood if we are to fully grasp the levels and consequences of segregation. The present study contributes to the research on daily mobility patterns in rela- tion to residential segregation. We analyse daily mobility patterns from neighbourhoods with different ethnic composition in terms of the likelihood of staying put, distance travelled, and the composition of neighbourhoods visited. The distinction of neighbourhoods on the basis of the immigrant population is important. Previous research has demonstrated that mobility patterns are in themselves segregated (e.g., Östh, Shuttleworth, \& Niedomysl, 2018; Phillips, Levy, Sampson, Small, \& Wang, 2019; Silm \& Ahas, 2014a, 2014b; Q. Wang, Phillips, Small, \& Sampson, 2018). Overall mobility rates, destinations, and exposure to different environments vary by income, ethnic/racial/language groups, and the characteristics of the origin neighbourhood. The overall aim of the article is to compare and contrast daily mobility patterns from areas of different immigrant composition, in order to discuss how and if residential segregation is overcome by mobility.

Our case study areas are two medium-sized Swedish labour market regions. The size of the chosen regions makes this study stand out from previous work (especially the US-based studies) which has mainly focused on larger cities. In a big city characterized by large distances and multiple local city centres, geographically differentiated mobility patterns are to be expected. Long distances prevent mobility, especially at locations where transport links are poor. In our case study regions, however, most distances can be covered by bike and public transportation is available for most. Population density, degree of cosmopolitanism, and level of segregation are also factors that affect mobility patterns (Phillips et al., 2019). Our case study regions are less densely populated and also have lower levels of segregation compared to large international cities. A second aim of the article is thus to compare the overall daily mobility patterns, in relation to segregation, in medium-sized regions to the results of previous work.

The article answers the following research questions:

- How do daily mobility patterns, in terms of stayers, movers, and mover destinations, differ between neighbourhoods of different immigrant composition? How do these differences relate to overall patterns of residential segregation?

- How do our results, from relatively small regions characterised by short distances and low levels of segregation (in an international comparison), relate to previous findings from large cities/high segregation contexts?

\section{Literature Review}

Whereas the vast bulk of segregation research focuses on the residential domain, it is increasingly recognized that the place of residence does not capture people's full exposure (van Ham \& Tammaru, 2016). A small but growing literature is looking into segregation in 
domains other than residence, such as work, school, and leisure (examples of studies include E. K. Andersson, Östh, \& Malmberg, 2010; Bygren, 2013; Ellis, Wright, \& Parks, 2004; Reardon, 2016; Silm \& Ahas, 2014a). An even smaller number of studies set out to compare levels of segregation in different domains. For example, Hall, Iceland, and Yi (2019; see also Ellis et al., 2004) show that residential segregation levels are substantially higher than 'workhood segregation' in the United States. In line with their results, analyses of diurnal mobility patterns in Sweden (Östh et al., 2018) and Estonia (Silm \& Ahas, 2014b) find that residential segregation is greater than segregation during the daytime. Marcińczak, Tammaru, Strömgren, and Lindgren (2015) find a close association between residential and workplace segregation in the Stockholm metropolitan region (cf. Pendakur, Pendakur, \& Bevelander, 2016, who find little correlation between residential and workplace segregation) whereas Tammaru, Strömgren, van Ham, and Danzer (2016) find very high levels of workplace segregation for newly arrived immigrants to Sweden from the Global South. However, after an initial period of about five years, workplace segregation tends to drop while residential segregation levels remain high. These results thus suggest that people experience lower levels of segregation, and thus in-group exposure, during the day-time, as a consequence of moving into other parts of the city and mixing with others outside of their local neighbourhood. Additionally, Toomet, Silm, Saluveer, Ahas, and Tammaru (2015; see also Kukk, van Ham, \& Tammaru, 2017) show that segregation in leisure in Tallinn is far less pronounced than that in both residential and workplace segregation.

There is also a small but growing literature directly concerned with daily mobility patterns in relation to segregation. Part of this research set out to analyse differences in 'activity spaces,' i.e., the geographical areas within which most daily activities occur (for an overview see Cagney, York Cornwell, Goldman, \& Cai, 2020). Such spaces are rarely defined by the boundaries of the residential neighbourhood. For example, Shelton, Poorthuis, and Zook (2015) show that the activity spaces of the inhabitants of Louisville's (KY) deprived West End areas are best described as 'fluid,' often crossing into other parts of the city.

A general conclusion is that activity spaces differ between residents in different neighbourhoods, depending on the neighbourhood's relative location, ethnic/racial composition, and social status (Östh, Malmberg, \& Andersson, 2014; D. Wang, Li, \& Chai, 2013; Zhang, Wang, Kwan, \& Chai, 2019). A number of US-based studies have demonstrated that the daily mobility of White, Black, and Hispanic populations takes place mostly in and around areas where the own population group is overrepresented (Browning, Calder, Soller, Jackson, \& Dirlam, 2017; Chen \& Pope, 2020; Jones \& Pebley, 2014; Phillips et al., 2019; Sampson, 2019; Shareck, Kestens, \& Frohlich, 2014; Q. Wang et al., 2018; Wong \& Shaw, 2011). There is also a distinct class dimen- sion (Q. Wang et al., 2018). Low-income neighbourhoods dominated by Blacks are especially likely to have other low-income areas as both main sending and receiving areas (Sampson, 2019). These results suggest that daily mobility patterns do not necessarily reduce own-group exposure. Rather, segregated mobility patterns may actually reinforce socioeconomic isolation.

A major explanation for the recent increase in the number of studies analysing residential segregation in relation to moving patterns and/or segregation in other domains is improved access to data. For long, analyses of daily mobility patterns relied on data from travel diaries or surveys, or register data covering home and workplace. Recent technological developments have resulted in increasing numbers of scholars having access to geocoded fine-grained datasets covering large populations. Data based on social media posts, GPS tracking, or mobile phone records provide better means to conduct detailed analyses of spatiotemporal activity patterns. Much of the recent U.S. research on segregated mobility patterns (e.g., Phillips et al., 2019; Sampson, 2019; Shelton et al., 2015; Q. Wang et al., 2018) rely on geocoded data from Twitter and other social media. Another source of fine-grained data suitable for mobility analyses is mobile phone records. Estonian segregation scholars have been especially productive in making use of phone data. Their analyses reveal that the two major language groups in Estonia, Estonian speakers and Russian speakers, exhibit quite different mobility patterns (Järv, Müürisepp, Ahas, Derudder, \& Witlox, 2014; Silm \& Ahas, 2014a, 2014b; Toomet et al., 2015). Russian speakers (identified by choice of preferred language when signing the contract with the operator) generally have more geographically concentrated activity spaces compared to the Estonian-speaking majority, and they tend to visit fewer places. Russian speakers are also more likely to visit areas where Russian speakers are overrepresented. The largest differences are found in relation to trips out of the study population's home city of Tallinn, but the ethnic pattern is clear also for intra-city mobility. Silm, Ahas, and Mooses (2018) add an age perspective to the analyses. Contrary to spatial assimilation theory, they find no evidence of adaptation over generations: differences in activity spaces are in fact largest in younger age groups.

There is also a growing number of Swedish studies that make use of mobile phone data to analyse mobility and transport patterns, temporal activity patterns and segregation (see, e.g., Blind, Dahlberg, Engström, \& Östh, 2018; Dahlberg et al., 2020; Östh et al., 2018; Toger, Shuttleworth, \& Östh, 2020). In line with previous research, the Swedish mobile phone studies show that residential segregation is on average more pronounced than daytime segregation. Hence, equating exposure with night-time population composition is erroneous, as stipulated by Kwan's (2012) uncertain geographic context problem. However, low-amenity areas with no or few job opportunities become more segregated during 
the day. This result, together with the US and Estonian findings of segregated mobility patterns, calls for more research into how mobility patterns differ between neighbourhoods of different population compositions and different positions in the urban hierarchy.

\section{Data and Method}

The data used in this study draws from two microdatabases. The first being a population register database, GeoSweden, whose material is compiled and distributed by Statistics Sweden. This population database is longitudinal and contains discrete and annually updated demographic, socio-economic, and geographic individual-level data. We use this population register data (from 2017, the latest year available) to obtain area characteristics, by aggregating the individual data on geographic location. Our main variable for aggregation is the percentage born outside Europe (the most common birth countries being Syria, Iraq, Iran, Afghanistan, Somalia, Turkey, Eritrea, Thailand, India, China, and Lebanon). We categorize areas in three groups based on their share of nonEuropeans: category 1, areas with a low share (below the mean, decile 1-7); category 2 , areas with a relatively high share (around or above the mean, decile 8-9); and category 3 , areas with a high share (the top decile). Although we focus on non-European immigrant concentration, our neighbourhood categorization is also a good reflection of the area's socio-economic characteristics. There is a strong correlation between percentage non-European immigrants and percentages of people with low education, on a low income, or in unemployment, and most of the areas belong to category 3 (with the highest share non-Europeans) and can be described as 'deprived' (see Table 1 for descriptive statistics of the three neighbourhood categories in the case study regions).

To track daily mobility patterns, we use mobile phone data. The MIND database is a Big Data database containing mobile-phone mobility data from one of the major phone operators in Sweden (including around 10-20\% of the Swedish population). The MIND dataset tracks (turned-on) phones through their connectedness to GSM-elements mounted on cell-towers. Calling, texting or uploading/downloading is recorded as an event, which means that a temporary phone-ID can be connected to a geocoded point (location of the cell tower). As a phone moves, the service of other GSM-elements take over, and a new geocoded location is recorded. The original data set contains data from every day over multiple years and is obviously too large to make any sense of. We select a workday that has been found to be representative for workdays in general-Thursday, 28 March 2019 (Toger et al., 2020). To test for differences between workdays and holidays (and as a check of robustness), we also select a second day-Saturday, March 30, 2019. As the main focus of this article is daily mobility during workdays, the Saturday results are used sparsely in the article. In 2017, the Swedish Internet agency esti- mated that $98 \%$ of the population owned a mobile phone (Internetstiftelsen, 2017), meaning that mobile phone usage is not restricted to specific demographic groups, though usage is lower among very young and very old.

The Swedish phone data has greater spatio-temporal resolution compared to the Estonian data, but unlike the Estonian data, there is no information on the phone user. The data can only be connected to the registry data on the basis of geography. For determining a crude residential location of each phone, we take the average durationweighted coordinates of the cell-towers that were connected to between $0.30 \mathrm{am}$ and $7.20 \mathrm{am}$. The estimated geocoded location is then aggregated to the $\mathrm{km}^{2}$ midpoint. This procedure renders a spatial representation of a residence that is shared with all other phones ending up within the same $\mathrm{km}^{2}$ unit. The $\mathrm{km}^{2}$ unit is hence the basic geographical entity used in this article. We acknowledge that a $\mathrm{km}^{2}$ unit may differ from a 'neighbourhood,' both administratively and in the minds of people. Yet, we argue that a $\mathrm{km}^{2}$ unit still corresponds fairly well to what people think of as their nearby area. The areas are also small enough to provide a nuanced pattern of immigrant concentration.

For day-activities, a similar approach is used where the day $\mathrm{km}^{2}$ midpoint is calculated using the durationweighted coordinates of the phone between 10 am and $12 \mathrm{am}$, and $1 \mathrm{pm}$ and $3 \mathrm{pm}$. The lunch hour is omitted since many phones leave the location of work or schooling for lunch, and our intention is to capture the location used for work, school or other daily activities. In addition to estimating the locations of night-rest and day-activity of each phone, we also calculate mobility behaviour variables for each phone. We aggregate these variables to the night-rest $\mathrm{km}^{2}$ units so that results can be used to represent the mobility behaviour of the population in each unit. Two measures are developed: total distance and maximum distance. Total distance $T D$ is formulated as:

$$
T D_{i}=\sum_{i} \sum_{t} \operatorname{Dist}\left(b t w x y_{e}-b t w x y_{e-1}\right)
$$

Where $i$ represents the individual phone, $t$ represents the time frame of $24 \mathrm{~h}$, and $e$ represents the event being recorded as a phone-to-mast connection. The phone's first observed position during a $24 \mathrm{~h}$ window $(t)$ is computationally made equal to the coordinate of the celltower providing the first-used GSM service. The subsequent coordinates represent the between (btw)-XYposition between the currently used cell-tower, and the last known between-XY-position. This means that the $x$-coordinate ( $y$-coordinate is calculated using the same method) is calculated as:

$$
b t w x=\min \left(x_{m, i, \min }, x_{e}\right)+\frac{1}{2} a b s\left(x_{m, i, \min }-x_{e}\right)
$$

where $m, i$, min represents the GSM-mast of phone $i$ at time $\min$ (i.e., the most recent location), and $x_{e}$ represents the last observed position of any event. This means that the list of locations is updated and grows, and can (as expressed in formula 1) be summed up at phone level. 
The maximum distance variable expresses the longest cartesian distance travelled from the coordinates associated with night rest. The calculation can be formulated as follows:

$$
M D_{i t}=\max \sqrt{\left(x_{o}-b t w x_{j}\right)^{2}+\left(y_{o}-b t w y_{j}\right)^{2}}
$$

Where $o$ represents the estimated location of residence, and $j$ represents all other visited locations during a 24-hour period.

The article is mostly descriptive in character. We present a set of tables, graphs, and maps showing the share of stayers, movers within the region, and movers leaving the region from each specific area category. Since the categories are of different size in terms of both population and $\mathrm{km}^{2}$ units, actual moving patterns are compared to anticipated patterns following the rela- tive size of each category. For example, since $70 \%$ of the population in each region reside in a $\mathrm{km}^{2}$ belonging to category 1 , we anticipate that $70 \%$ of all phones in each region will start in a category 1 unit. We further anticipate that $70 \%$ of those phones-i.e., $49 \%$ of all phoneswill remain in a category 1 unit. Numbers higher than $49 \%$ means an overrepresentation of mobility between category 1 units.

The descriptive analyses are complemented by two linear regressions, to control for basic demographic, socioeconomic, and geographic features of the $\mathrm{km}^{2}$ units (see Table 1). The regressions use the share of stayers and distance travelled as dependent variables. These regressions confirm the descriptive patterns in our tables and graphs; for reasons of space and clarity, we have chosen to only refer to results using text. Results are available from the authors upon request.

Table 1. Descriptive statistics of the two regions, total and by area category.

\begin{tabular}{|c|c|c|c|c|c|c|c|c|}
\hline & \multicolumn{4}{|c|}{ Falun-Borlänge LMR } & \multicolumn{4}{|c|}{ Gävle-Sandviken LMR } \\
\hline & Total & Category 1 & Category 2 & Category 3 & Total & Category 1 & Category 2 & Category 3 \\
\hline Population & 158,030 & 122,066 & 24,812 & 11,152 & 146,699 & 90,612 & 37,502 & 18,585 \\
\hline $\begin{array}{l}\text { Share } \\
\text { non-Europeans }\end{array}$ & $7.6 \%$ & $3.2 \%$ & $14.1 \%$ & $41.8 \%$ & $11.1 \%$ & $4.2 \%$ & $17.2 \%$ & $32.4 \%$ \\
\hline Mean age & 42.1 & 43.3 & 40.8 & 32.5 & 41.6 & 42.4 & 41.0 & 38.7 \\
\hline $\begin{array}{l}\text { Share with } \\
\text { children }(20+)\end{array}$ & $26.1 \%$ & $26.7 \%$ & $20.9 \%$ & $33.6 \%$ & $26.7 \%$ & $28.6 \%$ & $22.5 \%$ & $26.4 \%$ \\
\hline $\begin{array}{l}\text { Share single } \\
\text { parents }(20+)\end{array}$ & $4.1 \%$ & $3.6 \%$ & $5.2 \%$ & $8.4 \%$ & $4.5 \%$ & $3.8 \%$ & $5.2 \%$ & $6.5 \%$ \\
\hline $\begin{array}{l}\text { Share with } \\
\text { low education } \\
\text { (<10 years) }(20+)\end{array}$ & $18.1 \%$ & $16.7 \%$ & $19.8 \%$ & $32.8 \%$ & $20.3 \%$ & $18.3 \%$ & $21.4 \%$ & $28.5 \%$ \\
\hline $\begin{array}{l}\text { Share with } \\
\text { high education } \\
\text { (>14 years) }(20+)\end{array}$ & $16.0 \%$ & $17.0 \%$ & $13.9 \%$ & $8.1 \%$ & $15.4 \%$ & $16.5 \%$ & $15.4 \%$ & $9.6 \%$ \\
\hline $\begin{array}{l}\text { Share } \\
\text { unemployed } \\
(20-64)\end{array}$ & $10.4 \%$ & $7.8 \%$ & $15.3 \%$ & $28.4 \%$ & $12.6 \%$ & $8.5 \%$ & $16.6 \%$ & $23.7 \%$ \\
\hline $\begin{array}{l}\text { Share with low } \\
\text { disposable } \\
\text { income }(20+)\end{array}$ & $18.1 \%$ & $16.0 \%$ & $20.3 \%$ & $39.4 \%$ & $18.2 \%$ & $14.6 \%$ & $20.7 \%$ & $31.5 \%$ \\
\hline $\begin{array}{l}\text { Share living } \\
\text { in rentals }\end{array}$ & $22.9 \%$ & $14.0 \%$ & $47.0 \%$ & $70.0 \%$ & $29.4 \%$ & $15.2 \%$ & $51.1 \%$ & $54.9 \%$ \\
\hline $\begin{array}{l}\text { Number of } \mathrm{km}^{2} \\
\text { units }\end{array}$ & 1856 & 1725 & 90 & 41 & 1235 & 1179 & 38 & 18 \\
\hline $\begin{array}{l}\text { Population per } \\
\mathrm{km}^{2} \text { unit }\end{array}$ & 85.5 & 63.8 & 354.2 & 394.2 & 118.8 & 86.9 & 750.9 & 876.2 \\
\hline $\begin{array}{l}\text { Mean distance to } \\
\text { urban core }(\mathrm{km})\end{array}$ & 23.9 & 24.3 & 17.0 & 21.8 & 19.9 & 20.0 & 16.3 & 18.9 \\
\hline
\end{tabular}

Note: Night-time population (registry data). 


\section{The Case Study Regions}

An important contribution of the article is the focus on medium-sized regions, characterized by relatively short distances. The case study areas are two labour market regions located in mid-Sweden, Falun-Borlänge and Gävle-Sandviken. Labour market regions are functional geographical entities defined on the basis of commuting patterns. Hence, most workday mobility takes place within a labour market region. Aside from location, the two regions share many similarities: They are similar in population size, having roughly 150,000 inhabitants each and can both be described as bi-nodal, formed by two major cities (Falun and Borlänge, Gävle and Sandviken) and the surrounding area (including both smaller cities and countryside). Whereas Falun-Borlänge is somewhat larger in size (reflected by the larger number of $\mathrm{km}^{2}$ units, 1,856 compared to 1,235 in Gävle-Sandviken; see Table 1 and Figure 1), neither of the regions is highly concentrated or highly dispersed. A majority of the population in both regions live within biking distance or a short car/bus journey from the nearest major city. Like in most other Swedish regions, public transport opportunities are in most cases very good.

Falun-Borlänge has a somewhat smaller nonEuropean population $(7.6 \%$ of the total population, compared to $10.9 \%$ in Gävle-Sandviken) but somewhat higher levels of segregation (segregation index of 0.5 , compared to 0.42 in Gävle-Sandviken). The areas with the highest shares of non-Europeans are also more deprived, in terms of them having higher shares of inhabitants with low education, low incomes, and who are unemployed (which probably is a result of the higher concentration of non-Europeans) compared to category 3 units in Gävle-Sandviken. Category 3 units also have a higher share of single parents, people with low educa- tion, low-income earners, and people living in rental dwellings, all typical markers of relative deprivation in the Swedish context (see Table 1). Gävle-Sandviken, however, has a higher overall level of unemployment and people with low education.

Overall, the non-Europeans have a more concentrated residential pattern compared to the Swedish-born population. Almost three out of four non-Europeans live in about $25 \%$ of the populated territory, generally in or near the major cities (Figure 1), in areas that have a higher population density than more peripheral locations. As consequence, a vast majority of all units in our data are categorized as belonging to category 1 .

\section{Results}

The phones in our dataset can act in three different ways: remain in the home $\mathrm{km}^{2}$ unit, move to another $\mathrm{km}^{2}$ unit within the region, or leave the region. An individual staying put in the local neighbourhood is more exposed to local conditions than more mobile individuals. Hence, the 'stayers' are central to the analysis. The share of phones staying put is rather similar in both regions: $57 \%$ in Falun-Borlänge (Figure 2, left) and 59\% in Gävle-Sandviken (Figure 2, right; slightly higher during Saturdays). The number may appear high, but one must remember that the entire population includes children and the elderly. The share of phones staying put is somewhat higher in areas from categories 2 and 3 than in areas from category 1 , at least in Falun-Borlänge. Phones starting in category 1 are more likely to leave the region. A regression analysis, including controls related to $\mathrm{km}^{2}$ unit demographic and socioeconomic composition, confirm that the (sometimes small) differences between categories in terms of share of stayers hold also when controlling for other area features (results not shown).

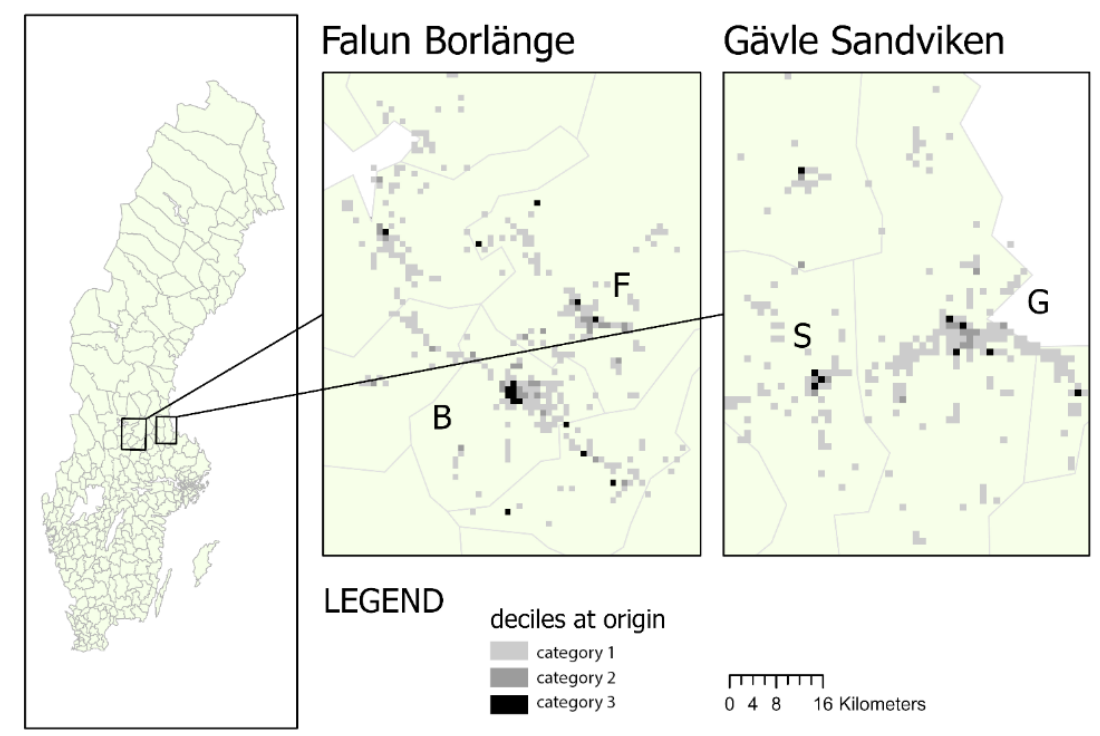

Figure 1. Distribution of $\mathrm{km}^{2}$ units by category in the two labour market regions. Notes: Empty areas are unpopulated. The map of Sweden indicates the location of the two regions. 
Falun-Borlänge LMR

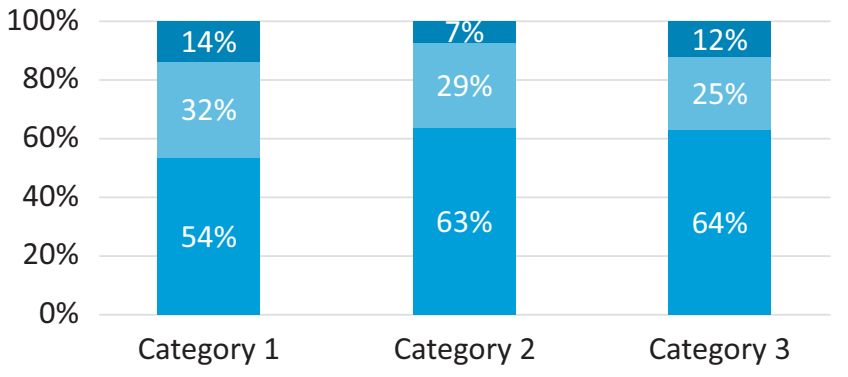

Gävle-Sandviken LMR

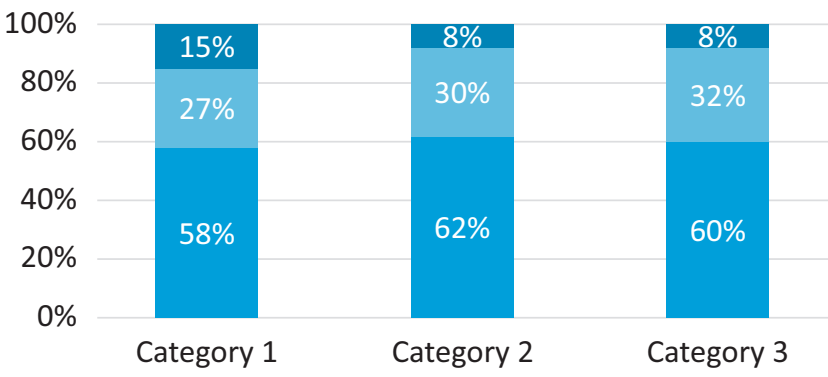

Leaving the region

Leaving the $\mathrm{km}^{2}$ unit but not the region

- Staying in own $\mathrm{km}^{2}$ unit

Figure 2. Share of phones staying within their own $\mathrm{km}^{2}$, leaving their own $\mathrm{km}^{2}$, and leaving the region: Falun-Borlänge (left) and Gävle-Sandviken (right). Note: Data from 28 March 2019, Thursday.

The share of stayers is higher in areas where the share of non-Europeans is at or above the mean. However, results are only valid for Thursdays. For Saturdays, the ethnic composition is insignificant.

Phones originating in categories 2 and 3 are not only more likely to stay put, they also travel shorter distances when they do move. Figure 3 displays the longest distance phones travel and total distance travelled over the course of a day, by category of the area of origin (mean values). Results show that phones starting in category 1 units are not only more mobile-those who travel are also more mobile in terms of how far they travel. Phones starting in categories 2 and 3 are more likely to remain relatively close to the areas of origin. The average maximum distance travelled is about or less than $3 \mathrm{~km}$ for phones starting in categories 2 and 3 in Falun-Borlänge and category 2 in Gävle-Sandviken. The pattern remains when running a regression, controlling for basic demographic and socioeconomic features (results not shown). The regression model also includes distance to the urban core. Hence, differences between categories are not (only) due to differences in locations.

Distance says something about the general travel behaviour of different groups (or, in this case, phones starting in different area categories) but they do not show where people go. In order for daily mobility to reduce exposure to their own neighbourhood environment, people need not only to travel but also to travel to areas different from their own neighbourhood. Previous research suggests that mobility patterns are segregated in the sense that people are more inclined to travel to areas where their own group is overrepresented. Hence, daily mobility does not overcome residential segregation to the extent that would have been the case if travel patterns had been more similar across groups.

Tables 2 shows the origin and destination for the Falun-Borlänge phones data. Table 3 does the same for the Gävle-Sandviken data. Each destination category contains three columns: actual mobility to units that are categorized according to night-time population (registry data), actual mobility to units that are categorized according to daytime population (phone data), and anticipated values. The anticipated values are based on population size. Since $70 \%$ of the population reside in category 1 units, we anticipate that $70 \%$ of all moves are conducted by phones originating in a category 1 unit and that $70 \%$ of those moves (or $49 \%$ of the total number of moves) are conducted within the category 1 segment.

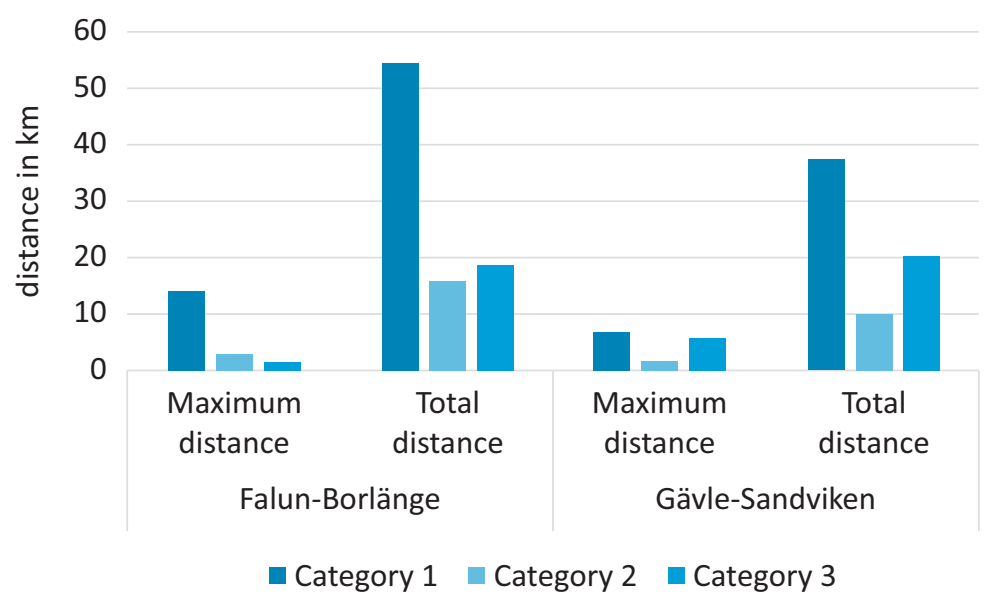

Figure 3. Maximum distance and total distance travelled by area category and region. Note: Data from 28 March 2019 , Thursday. 
Table 2. Flows across area categories (Falun-Borlänge).

\begin{tabular}{|c|c|c|c|c|c|c|c|c|c|c|c|}
\hline & & & & & & estinatior & & & & & \\
\hline & & ategory 1 & & & ategory 2 & & & ategory 3 & & Tot & \\
\hline Origin & $\begin{array}{c}\text { Actual } \\
\text { values } \\
\text { Registry } \\
\text { data }\end{array}$ & $\begin{array}{c}\text { Actual } \\
\text { values } \\
\text { Phone } \\
\text { data }\end{array}$ & $\begin{array}{l}\text { Anti- } \\
\text { cipated } \\
\text { values }\end{array}$ & $\begin{array}{c}\text { Actual } \\
\text { values } \\
\text { Registry } \\
\text { data }\end{array}$ & $\begin{array}{c}\text { Actual } \\
\text { values } \\
\text { Phone } \\
\text { data }\end{array}$ & $\begin{array}{l}\text { Anti- } \\
\text { cipated } \\
\text { values }\end{array}$ & $\begin{array}{c}\text { Actual } \\
\text { values } \\
\text { Registry } \\
\text { data }\end{array}$ & $\begin{array}{c}\text { Actual } \\
\text { values } \\
\text { Phone } \\
\text { data }\end{array}$ & $\begin{array}{l}\text { Anti- } \\
\text { cipated } \\
\text { values }\end{array}$ & $\begin{array}{c}\text { Actual } \\
\text { values } \\
\text { Registry } \\
\text { data }\end{array}$ & $\begin{array}{c}\text { Anti- } \\
\text { cipated } \\
\text { values }\end{array}$ \\
\hline Category 1 & $63.1 \%$ & $49.2 \%$ & $49.0 \%$ & $3.0 \%$ & $16.6 \%$ & $14.0 \%$ & $1.4 \%$ & $1.7 \%$ & $7.0 \%$ & $67.5 \%$ & $70.0 \%$ \\
\hline Category 2 & $4.1 \%$ & $0.8 \%$ & $14.0 \%$ & $15.7 \%$ & $10.9 \%$ & $4.0 \%$ & $0.8 \%$ & $2.0 \%$ & $2.0 \%$ & $20.7 \%$ & $20.0 \%$ \\
\hline Category 3 & $1.5 \%$ & $0.0 \%$ & $7.0 \%$ & $1.0 \%$ & $1.0 \%$ & $2.0 \%$ & $9.3 \%$ & $10.7 \%$ & $1.0 \%$ & $11.8 \%$ & $10.0 \%$ \\
\hline Total & $68.7 \%$ & $50.0 \%$ & $70.0 \%$ & $19.7 \%$ & $28.5 \%$ & $20.0 \%$ & $11.6 \%$ & $21.5 \%$ & $10.0 \%$ & $100.0 \%$ & $100.0 \%$ \\
\hline
\end{tabular}

Note: Data from 28 March 2019, Thursday.

The anticipated values should be compared to actual mobility to detect over-or under-representation.

The left-hand column in each category show destinations for all phones by origin area category, with destination units categorized according to night-time population. Comparing actual destinations based on registry data to the anticipated values yields that there is a strong orientation towards the own category. The percentages of phones staying in their own category are far above the anticipated values, for all categories in both regions. This is partly due to a very large share of phones staying in their own $\mathrm{km}^{2}$ unit, but there is also a strong bias towards the own category among those that do move to another unit. In both regions, over $80 \%$ of all phones leaving a category 1 unit go to another category 1 unit (the anticipated value is $70 \%$ ). For categories 2 and 3 , the shares are at about $25 \%$ in Falun-Borlänge. These values are all well above the anticipated values of 70/20/10. In Gävle-Sandviken, numbers are lower for categories 2 and 3 ( $18 \%$ vs $6 \%$ respectively) which is in line with the total share of phones starting from each category.

That phones in our dataset display a clear tendency to either remain in the home $\mathrm{km}^{2}$ unit or move to other areas within the same category result in an underrepresentation of phones travelling to other area categories. The share of phones leaving category 1 for a category 2 or 3 area is well below the anticipated values.
The same goes for phones leaving the other categories. Phones leaving category 3 areas are especially unlikely to travel to a category 1 area. Only $1.5 \%$ and $1.1 \%$ of all phones (for Falun-Borlänge and Gävle-Sandviken respectively) start in a category 3 area and go to a category 1 area, compared to an expected value of $7 \%$.

The phones' actual movements across space are displayed in Figures 4-6. The maps show flows of phones starting in each of the three area categories. Phones starting in category 1 move all across the regions. Although most flows are within or between the major cities, there are a large number of flows travelling to/from more peripheral locations and over long distances. Phones starting in category 2 units are more concentrated in the major cities. In Gävle-Sandviken, much movement takes places within the city of Gävle. In Falun-Borlänge, there are more flows between cities and also to smaller, more peripheral cities but there is still a higher concentration of flows to certain places, compared to flows starting in category 1 units. Flows starting in category 3 units are even more concentrated. Almost all flows go to areas within the major cities.

That people travel does however mean that the composition of neighbourhoods changes over the course of a day. Neighbourhoods that originally had a large or small proportion of non-European immigrants might become more mixed as people of different origins leave or visit

Table 3. Flows across area categories (Gävle-Sandviken).

\begin{tabular}{|c|c|c|c|c|c|c|c|c|c|c|c|}
\hline \multirow[b]{3}{*}{ Origin } & \multicolumn{11}{|c|}{ Destination } \\
\hline & \multicolumn{3}{|c|}{ Category 1} & \multicolumn{3}{|c|}{ Category 2} & \multicolumn{3}{|c|}{ Category 3} & \multicolumn{2}{|c|}{ Total } \\
\hline & $\begin{array}{c}\text { Actual } \\
\text { values } \\
\text { Registry } \\
\text { data }\end{array}$ & $\begin{array}{c}\text { Actual } \\
\text { values } \\
\text { Phone } \\
\text { data }\end{array}$ & $\begin{array}{c}\text { Anti- } \\
\text { cipated } \\
\text { values }\end{array}$ & $\begin{array}{c}\text { Actual } \\
\text { values } \\
\text { Registry } \\
\text { data }\end{array}$ & $\begin{array}{c}\text { Actual } \\
\text { values } \\
\text { Phone } \\
\text { data }\end{array}$ & $\begin{array}{c}\text { Anti- } \\
\text { cipated } \\
\text { values }\end{array}$ & $\begin{array}{c}\text { Actual } \\
\text { values } \\
\text { Registry } \\
\text { data }\end{array}$ & $\begin{array}{c}\text { Actual } \\
\text { values } \\
\text { Phone } \\
\text { data }\end{array}$ & $\begin{array}{c}\text { Anti- } \\
\text { cipated } \\
\text { values }\end{array}$ & $\begin{array}{c}\text { Actual } \\
\text { values } \\
\text { Registry } \\
\text { data }\end{array}$ & $\begin{array}{c}\text { Anti- } \\
\text { cipated } \\
\text { values }\end{array}$ \\
\hline Category 1 & $75.5 \%$ & $46.9 \%$ & $49.0 \%$ & $3.3 \%$ & $30.1 \%$ & $14.0 \%$ & $1.5 \%$ & $3.3 \%$ & $7.0 \%$ & $80.3 \%$ & $70.0 \%$ \\
\hline Category 2 & $3.2 \%$ & $0.8 \%$ & $14.0 \%$ & $10.4 \%$ & $2.6 \%$ & $4.0 \%$ & $0.5 \%$ & $10.7 \%$ & $2.0 \%$ & $14.1 \%$ & $20.0 \%$ \\
\hline Category 3 & $1.1 \%$ & $0.1 \%$ & $7.0 \%$ & $0.7 \%$ & $0.8 \%$ & $2.0 \%$ & $3.8 \%$ & $4.7 \%$ & $1.0 \%$ & $5.6 \%$ & $10.0 \%$ \\
\hline Total & $79.9 \%$ & $47.9 \%$ & $70.0 \%$ & $14.4 \%$ & $33.4 \%$ & $20.0 \%$ & $5.8 \%$ & $18.7 \%$ & $10.0 \%$ & $100.0 \%$ & $100.0 \%$ \\
\hline
\end{tabular}

Note: Data from 28 March 2019, Thursday. 
Gävle Sandviken

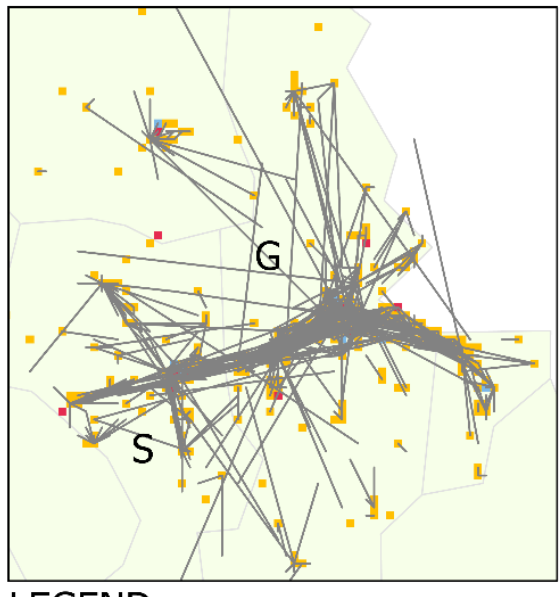

LEGEND

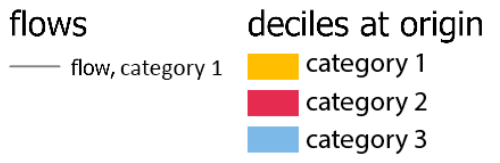

Falun Borlänge

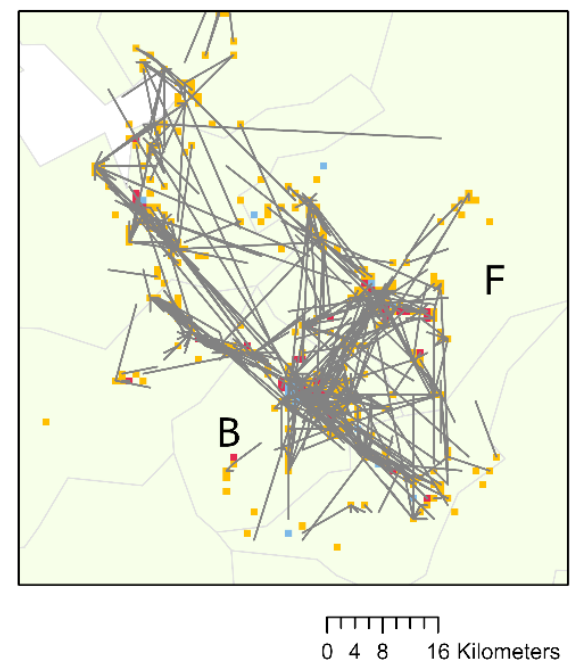

Figure 4. Flows starting in category 1. Note: Data from 28 March 2019, Thursday.

the area for work or other activities. Hence, the population composition at night does not necessarily reflect the population that people actually meet and interact with during the daytime. As discussed, phones starting in category 1 units are the most mobile. This might indicate that the population composition of category 1 units is more likely to change (due to both in-and out-mobility) than the composition of people in areas from categories 2 and 3, where a higher share of phones stay put. However,

\section{Gävle Sandviken}

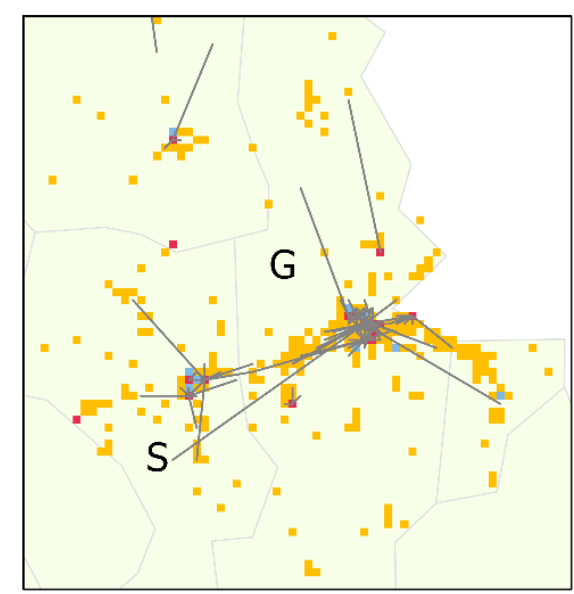

LEGEND

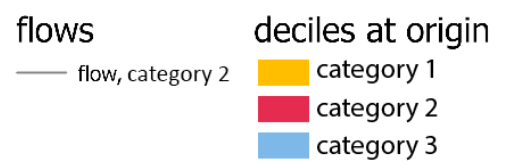

since flows are biased toward the own area category, the composition of people in category 1 units might not change as dramatically as might be expected, given the high number of movers.

The mid columns within each destination category in Tables 2 and 3 show flows where destinations are categorized according to the daytime population (phone data), rather than the night-time population. We let the characteristics of each phone's user reflect the population

\section{Falun Borlänge}

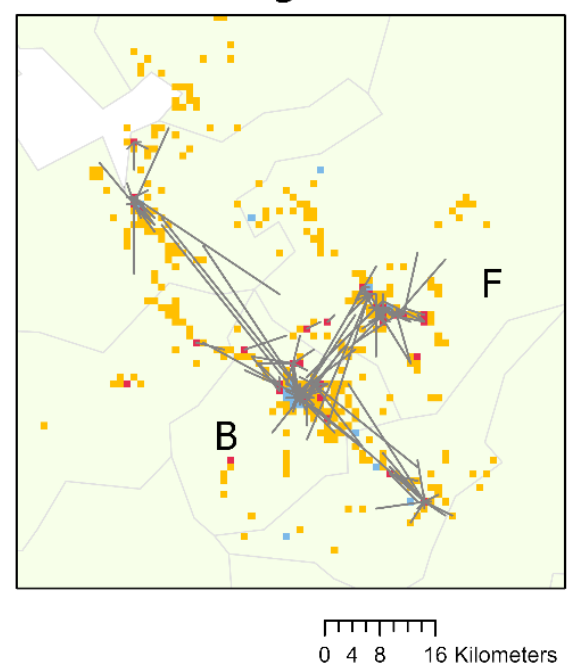

Figure 5. Flows starting in category 2. Note: Data from 28 March 2019, Thursday. 
Gävle Sandviken

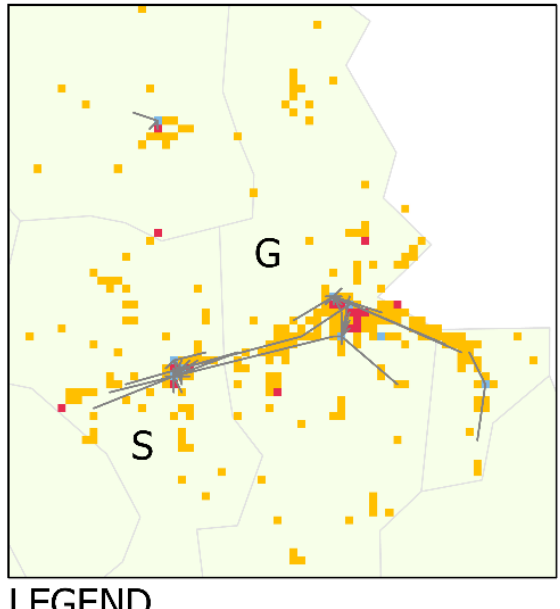

$\begin{array}{cc}\text { flows } & \text { deciles at origin } \\ \text { flow, category 3 } & \text { category 1 } \\ & \text { category 2 } \\ & \text { category 3 }\end{array}$
Falun Borlänge

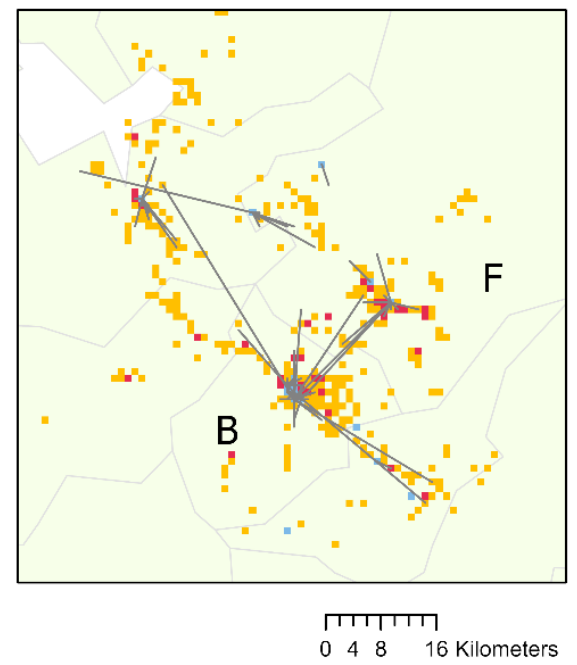

Figure 6. Flows starting in category 3. Note: Data from 28 March 2019, Thursday.

composition of its origin. Hence, a phone starting in a $\mathrm{km}^{2}$ unit with $50 \%$ non-Europeans is regarded as being 0.5 non-European. The categorization uses the same $70 / 20 / 10$ distribution as the categorization based on the registry data.

When categorising areas according to daytime population, a substantially larger share of all phones travel to areas belonging to categories 2 and 3. About $50 \%$ of all phones go to areas from categories 2 or 3 , compared to the anticipated $30 \%$. Hence, exposure to nonEuropean people is much larger than exposure to neighbourhoods where non-Europeans reside. However, most phones still travel within their own neighbourhood category. The large share of phones travelling to areas from category 3 are mainly made up of phones start- ing in categories 2 and 3. Most phones starting in category 1 remain in areas from category 1 . They are slightly overrepresented in category 2 , in relation to anticipated values, but not for category 3 destinations. Very few phones starting in categories 2 and 3 travel to category 1. Hence, results suggest that mobility patterns remain highly segregated also when looking at daytime rather than night-time populations.

As a final exercise, we checked to what extent area categorization changes on the basis of phones travelling across space (Figure 7). Category 1 units are reclassified to the least extent. About $75 \%$ of all $\mathrm{km}^{2}$ units classified as a category 1 using night-time registry data are also classified as category 1 units when using daytime phone data. Around $20 \%$ are reclassified to category 2 and

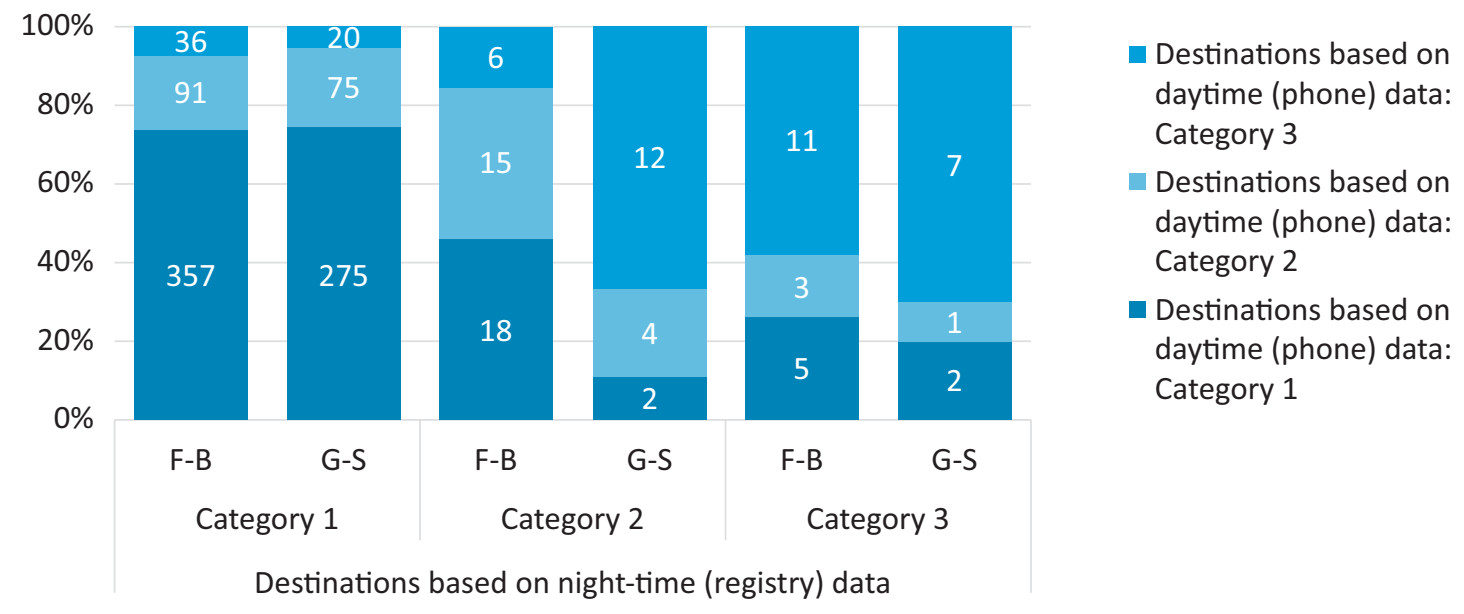

Figure 7. Comparison of the categorization of destinations based on registry data (night-time population) vs. phone data (daytime population). Note: 28 March 2019, Thursday. 
about $5 \%$ to category 3 . Of course, one should keep in mind that category 1 includes all areas with a share nonEuropeans below the mean. Hence, some areas need a large inflow of non-Europeans to become reclassified. Areas belonging to the other categories are reclassified to a larger extent. In Falun-Borlänge, 18 out of 39 areas in category 2 are reclassified into category 1 on the basis of the phone data, meaning that there is either a large inflow of phones originating in category 1 , or that a smaller inflow of category 1 phones is combined with an outflow of phones from category 2. In Gävle-Sandviken, many category 2 units are also reclassified but into category 3. Hence, the inflow in Gävle-Sandviken to category 2 units is dominated by phones originating in category 3 . As for areas from category 3 , a majority remain so in both Falun-Borlänge and Gävle-Sandviken. The overall pattern is similar for Saturdays.

These results support the conclusion that phones travel between areas from categories 2 and 3 but that there is less exchange with category 1 units. Phones starting in category 1 travel often and far, but mostly to similar areas. Phones starting in category 2 and especially category 3 are more likely to stay put in their own region. When they do move, most phones go to other areas with a relatively high share of non-Europeans. These are not necessarily the most immigrant-dense residential areas-especially not for phones starting in category 2 units-but areas where a lot of non-Europeans gather during the day-time. Hence, while mobility may alleviate segregation to some extent, we find that mobility patterns are highly segregated which affect people's overall exposure to both places and people.

\section{Discussion and Conclusions}

Most individuals experience many different environments during the course of the day. They travel to work or school, to see family and friends, and for other activities such as shopping, leisure activities, or simply for fun or exercise. Yet, the academic literature on segregation and neighbourhood effects have failed to sufficiently incorporate this into their theoretical framework and methodological approaches. A vast majority of the literature ignores daily mobility, indirectly assuming that the place of residence accounts for an individual's full exposure to place and other people. The result is potentially biased estimates of both levels of segregation and, in particular, its consequences. Exposure to the physical environment and the people inhabiting it are among the main mechanisms that produce neighbourhood effects (see Galster, 2012). It has been suggested that failure to estimate exposure, by ignoring mobility (referred to as the 'uncertain geographic context problem') is one of the most serious methodological challenges facing neighbourhood effect research.

Recently, there have been calls to broaden the scope of segregation. A small but growing number of studies empirically assess residential segregation in relation to segregation in other domains (predominantly work). They generally find workplace/daytime segregation to be lower, meaning that people leave their home neighbourhoods during the daytime to mix with other people in other environments. Our results support these findings. About half of the phones in our sample leave their home $\mathrm{km}^{2}$ units during the daytime, and one should keep in mind that the sample includes both the elderly and children. Travelling $5-10 \mathrm{~km}$ is not unusual. Hence, our results support the need stressed by M. P. Kwan, Y. M. Park and others (e.g., Kwan, 2012; Park \& Kwan, 2018) to broaden estimates of environment exposure beyond the residential neighbourhood. Like much previous research, this article focuses on daytime workday segregation or workplace segregation. Tentative conclusions from repeating our analyses for Saturdays are that patterns differ between workdays and holidays. We find that a higher share remains within their home $\mathrm{km}^{2}$ units on Saturdays and that differences between immigrant-dense and other areas disappear. Previous work on segregation in the leisure domain has however found segregation of leisure to be lower than residential segregation (e.g., Toomet et al., 2015), although evidence for this is scarce. More research is needed to better understand how mobility behaviour changes between workdays/working hours and holidays/spare time and how this affects overall levels of exposure to different environments.

However, in line with previous literature, our results also stress that mobility patterns are in themselves segregated. First, there are differences in mobility levels: People starting in areas with high shares of nonEuropeans are more likely to remain in their home unit. The higher levels of unemployment in these units are a probable contributing cause. Second, much of the daily mobility that takes place is oriented towards areas that have similar characteristics to the origin neighbourhood. This is true also when categorizing areas according to the daytime population. People not only go to areas where others from the same neighbourhood categories live but also to places where they go. Thus, although many people leave their home areas during the day, they are still overly exposed to people from similar environments. These findings are important in relation to discussions about exposure and estimates of neighbourhood effects. It is important to recognize that many people are exposed to areas other than the home neighbourhood, but equally important to address what type of environments they visit and whom they meet in these places. If mobility patterns are highly segregated, the residential neighbourhood is a much better proxy for total exposure compared to a situation where mobility results in a high degree of mix.

Our case study regions are relatively small by international standards, both in terms of population size and geographical scope. That we find similarly segregated mobility patterns in small Swedish labour market regions as did Q. Wang et al. (2018) for the 50 largest cities in the United States (and others have found for other 
contexts) suggest that segregated mobility patterns are also likely to exist in other cities and countries. The relatively short distances (reinforced by the bi-nodal structures) and good transportation opportunities in our case regions suggest that distance or access to means of travel alone cannot explain the segregated patterns. Other potential explanations are differences in the location of, and frequency of visits to, family and friends, work, and leisure activities. Results from the two regions are very similar, which strengthen the overall conclusions. Minor differences may be due to differences in either data coverage or regional characteristics. For example, the somewhat larger size of the Falun-Borlänge region explains the longer average travel distances. The higher level of segregation and higher level of deprivation in the Falun-Borlänge region might also explain the larger overrepresentation of flows within the category 3 segment. More in-depth analyses are needed to gain knowledge about how relative regional levels of segregation and deprivation affect overall daily mobility.

The results of this and other studies stress that segregation is more than where people live. It is also about how and to where we move, whom we meet, where we work, and how (where, with whom) we spend our spare time. These conclusions have implications for research, which so far has failed to sufficiently acknowledge these other domains in both theoretical models and empirical estimates. It also has implications for measures to combat segregation. To fight segregation and achieve a higher degree of mix, looking at the residential area alone is insufficient. On the other hand, focusing on exposure rather than neighbourhood environments provides more tools to combat segregation and reduce potential negative effects. To reduce exposure to certain environments or population groups, and to achieve a higher degree of mix, is likely to be much easier, cheaper, and faster to implement than measures which aim to change the set-up of the residential environment. Potential measures to increase the heterogeneity of mobility patterns and obtain a higher mix of population groups on a daily basis might include, among others, offering leisure activities in other areas, changing school catchment areas, or increasing initiatives for daily travel. Such measures might increase exposure to other environments and population groups, and hence reduce segregation by exposure, despite not having an (immediate) effect on the overall residential pattern. To further test how such measures affect exposure and segregation, and under what circumstances, is however a task for practitioners and future research.

\section{Acknowledgments}

Roger Andersson and Kati Kadarik are grateful for financial support from the EU Horizon 2020 research and innovation programme under grant agreement No. 870898 (Uplift). John Östh gratefully acknowledges the support from the Ax:son Johnson Foundation.

\section{Conflict of Interests}

The authors declare no conflict of interests.

\section{References}

Andersson, R., \& Musterd, S. (2010). What scale matters. Exploring the relationships between individuals' social position, neighbourhood context and the scale of neighbourhood. Geografiska Annaler B, 92(1), 23-43.

Andersson, E. K., Östh, J., \& Malmberg, B. (2010). Ethnic segregation and performance inequality in the Swedish school system: A regional perspective. Environment and Planning A, 42(11), 2674-2686.

Blind, I., Dahlberg, M., Engström, G., \& Östh, J. (2018). Construction of register-based commuting measures. CESifo Economic Studies, 64(2), 292-326.

Browning, C. R., \& Soller, B. (2014). Moving beyond neighborhood: Activity spaces and ecological networks as contexts for youth development. Cityscape: A Journal of Policy Development and Research, 16(1), 165-196.

Browning, C. R., Calder, C., Soller, B., Jackson, A. L., \& Dirlam, J. (2017). Ecological networks and neighborhood social organization. American Journal of Sociology, 122(6), 1939-1988.

Bygren, M. (2013). Unpacking the causes of ethnic segregation across workplaces. Acta Sociologica, 56(1), 3-19.

Cagney, K. A., York Cornwell, E., Goldman, A. W., \& Cai, L. (2020). Urban mobility and activity space. Annual Reviews of Sociology, 46(9), 1-26.

Chen, M. K., \& Pope, D. G. (2020). Geographic mobility in America: Evidence from cell phone data (NBER Working paper 27072). Cambridge, MA: National Bureau of Economic Research.

Dahlberg, M., Edin, P. A., Grönqvist, E., Lyhagen, J., Östh, J., Siretskiy, A., \& Toger, M. (2020). Effects of the covid-19 pandemic on population mobility under mild policies: Causal evidence from Sweden. New York, NY: Cornell University. Retrieved from https://arxiv.org/ abs/2004.09087

Ellis, M., Wright, R., \& Parks, V. (2004). Work together, live apart? Geographies of racial and ethnic segregation at home and at work. Annals of the Association of American Geographers, 94(3), 620-637.

Galster, G. C. (2012). The mechanism(s) of neighbourhood effects: Theory, evidence, and policy implications. In M. van ham, D. Manley, N. Bailey, L. Simpson, \& D. Maclennan (Eds.), Neighbourhood effects research: New perspectives (pp. 23-56). Dordrecht: Springer.

Galster, G., Andersson, R., \& Musterd, S. (2016). Neighbourhood social mix and adults' income trajectories: Longitudinal evidence from Stockholm. Geografiska Annaler Series B Human Geography, 98(2), 145-170. 
Grannis, R. (1998). The importance of trivial streets: Pedestrian street networks and geographic patterns of residential segregation. American Journal of Sociology, 103, 1530-1564.

Grannis, R. (2005). T-Communities: Pedestrian street networks and residential segregation in Chicago, Los Angeles, and New York. City \& Community, 4(3), 295-321.

Hall, M., Iceland, J., \& Yi, Y. (2019). Racial separation at home and work: Segregation in residential and workplace settings. Population Research and Policy Review, 38, 671-694.

Internetstiftelsen. (2017). Svenskarna och internet 2017. Undersökning om svenskarnas internetvanor [The Swedes and Internet 2017. A study of the Swedes' internet usage behaviour]. Stockholm: Internetstiftelsen. Retrieved from https://internetstiftelsen.se/ docs/Svenskarna_och_internet_2017.pdf

Järv, O., Müürisepp, K., Ahas, R., Derudder, B., \& Witlox, F. (2014). Ethnic differences in activity spaces as a characteristic of segregation: A study based on mobile phone usage in Tallinn, Estonia. Urban Studies, 52(14), 2680-2698.

Jones, M., \& Pebley, A. R. (2014). Redefining neighborhoods using common destinations: Social characteristics of activity spaces and home census tracts compared. Demography, 51(3), 727-752.

Kadarik, K., Miltenburg, E., Musterd, S., \& Östh, J. (2021). Country-of-origin-specific economic capital in neighbourhoods: Impact on immigrants' employment opportunities. Environment and Planning A. Advance online publication. https://doi.org/10.1177/03085 $18 \times 21989702$

Kasarda, J., \& Janowitz, M. (1974). Community attachment in mass society. American Sociological Review, 39, 328-339.

Kukk, K., van Ham, M., \& Tammaru, T. (2017). Ethnicity of leisure: A domains approach to ethnic integration during free time activities. Tijdschrift voor Economische en Sociale Geografie, 110(3), 289-302.

Kwan, M.-P. (2012). The uncertain geographic context problem. Annals of the Association of American Geographers, 102(5), 958-968.

Kwan, M.-P. (2018). The neighborhood effect averaging problem (NEAP): An elusive confounder of the neighborhood effect. International Journal of Environmental Research and Public Health, 15(9). https.//doi. org/10.3390/ijerph15091841

Marcińczak, S., Tammaru, T., Strömgren, M., \& Lindgren, U. (2015). Changing patterns of residential and workplace segregation in the Stockholm metropolitan area. Urban Geography, 36(7), 969-992.

Musterd, S. (2020). Towards further understanding of urban segregation. In S. Musterd (Ed.), Handbook of urban segregation (pp. 411-424). Cheltenham: Edward Elgar Publishing.

Musterd, S., Galster, G., \& Andersson, R. (2012). Temporal dimensions and the measurement of neigh- bourhood effects. Environment and Planning A, 44, 605-627.

Östh, J., Malmberg, B., \& Andersson, E. K. (2014). Analysing segregation using individualised neighbourhoods. In C. D. Lloyd, I. G. Shuttleworth, \& D. W. Wong (Eds.), Socio-spatial segregation: Concepts, processes and outcomes (pp. 135-162). Oxford: Oxford University Press.

Östh, J., Shuttleworth, I., \& Niedomysl, T. (2018). Spatial and temporal patterns of economic segregation in Sweden's metropolitan areas: A mobility approach. Environment and Planning A: Economy and Space, 50(4), 809-825.

Östh, J., \& Türk, U. (2020). Integrating infrastructure and accessibility in measures of bespoke neighbourhoods. In S. Musterd (Ed.), Handbook of urban segregation (pp. 378-394). Cheltenham: Edward Elgar Publishing.

Park, Y. M., \& Kwan, M.-P. (2018). Beyond residential segregation: A spatiotemporal approach to examining multi-contextual segregation. Computers, Environment and Urban Systems, 71, 98-108.

Pendakur, K., Pendakur, R., \& Bevelander, P. (2016). Are residential and workplace concentration correlated for immigrants? Evidence for Sweden. Journal of International Migration and Integration, 17, 687-706.

Phillips, N. E., Levy, B. L., Sampson, R. J., Small, M. L., \& Wang, R. Q. (2019). The social integration of American cities: Network measures of connectedness based on everyday mobility across neighborhoods. Sociological Methods and Research. Advance online publication. https://doi.org/10.1177/00491241198 52386

Reardon, S. F. (2016). School segregation and racial academic achievement gaps. RSF: The Russell Sage Foundation Journal of the Social Sciences, 2(5), 34-57.

Sampson, R. J. (2012). Great American city: Chicago and the enduring neighborhood effect. London and Chicago, IL: University of Chicago Press.

Sampson, R. J. (2019). Neighborhood effects and beyond: Explaining the paradoxes of inequality in the changing American metropolis. Urban Studies, 56(1), 3-32.

Shareck, M., Kestens, Y., \& Frohlich, K. L. (2014). Moving beyond the residential neighborhood to explore social inequalities in exposure to area-level disadvantage: Results from the interdisciplinary study on inequalities on smoking. Social Science and Medicine, 108, 106-114.

Shelton, T., Poorthuis, A., \& Zook, M. (2015). Social media and the city: Rethinking urban socio-spatial inequality using user-generated geographic information. Landscape and Urban Planning, 142, 198-211.

Silm, S., \& Ahas, R. (2014a). Ethnic differences in activity spaces: A study of out-of-home nonemployment activities with mobile phone data. Annals of the Association of American Geographers, 104(3), 542-559.

Silm, S., \& Ahas, R. (2014b). The temporal variation 
of ethnic segregation in a city: Evidence from a mobile phone use dataset. Social Science Research, 47, 30-43.

Silm, S., Ahas, R., \& Mooses, V. (2018). Are younger age groups less segregated? Measuring ethnic segregation in activity spaces using mobile phone data. Journal of Ethnic and Migration Studies, 44(11), 1797-1817.

Tammaru, T., Strömgren, M., van Ham, M., \& Danzer, A. M. (2016). Relations between residential and workplace segregation among newly arrived immigrant men and women. Cities, 59, 131-138.

Tan, Y., Kwan, M.-P., \& Chen, Z. (2020). Examining ethnic exposure through the perspective of the neighborhood effect averaging problem: A case study of Xining, China. International Journal of Environmental Research and Public Health, 17. https.//doi.org/ 10.3390/ijerph17082872

Toger, M., Shuttleworth, I., \& Östh, J. (2020). How average is average? Temporal patterns in human behaviour as measured by mobile phone data-Or why chose Thursdays. New York, NY: Cornell University. Retrieved from https://arxiv.org/abs/2005. 00137
Toomet, O., Silm, S., Saluveer, E., Ahas, R., \& Tammaru, T. (2015). Where do ethno-linguistic groups meet? How copresence during free-time is related to copresence at home and at work. PLOS One, 10(5). https:// doi.org/10.1371/journal.pone.0126093

van Ham, M., \& Tammaru, T. (2016). New perspectives on ethnic segregation over time and space. A domains approach. Urban Geography, 37(7), 953-962.

Wang, D., Li, F., \& Chai, Y. (2013). Activity spaces and sociospatial segregation in Beijing. Urban Geography, 33(2), 256-277.

Wang, Q., Phillips, N. E., Small, M. L., \& Sampson, R. J. (2018). Urban mobility and neighborhood isolation in America's 50 largest cities. Proceedings of the National Academy of Sciences of the United States of America, 115(30), 7735-7740.

Wong, D. W. S., \& Shaw, S.-L. (2011). Measuring segregation: An activity-space approach. Journal of Geographical Systems, 13(2), 127-145.

Zhang, X., Wang, J., Kwan, M.-P., \& Chai, Y. (2019). Reside nearby, behave apart? Activity-space-based segregation among residents of various types of housing in Beijing, China. Cities, 88, 166-180.

\section{About the Authors}

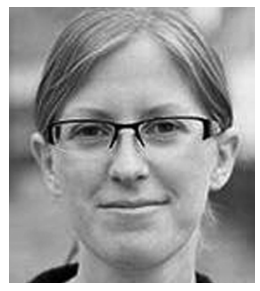

Lina Hedman currently works as an Analyst at the Centre for Research and Development, Uppsala University/Region Gävleborg, where her work centres on issues related to regional development and equity/equality. Lina holds a PhD in human geography from Uppsala University. She has published numerous research articles on topics related to residential segregation, residential mobility, and neighbourhood effects. Most of her research is based on quantitative analyses of large-scale individual-level data.

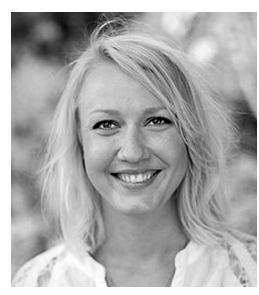

Kati Kadarik is a Human Geographer with a quantitative empirical focus. Her research interests concern migration, residential segregation, residential mobility, and inequality. She holds a PhD from Uppsala University and defended her doctoral thesis, "Moving Out, Moving Up, Becoming Employed: Studies in the Residential Segregation and Social Integration of Immigrants in Sweden," in 2019.

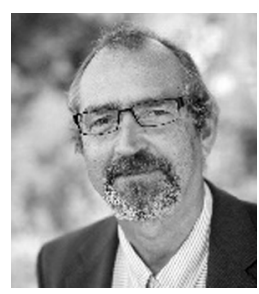

Roger Andersson (PhD) held the Chair in Human Geography at the Institute for Housing and Urban Research at Uppsala University from 1999 to 2019 and is now a Senior Professor in Human Geography at the same institute. He has published several books, many book chapters, and a large number of peer-reviewed articles in leading journals. Most publications have focused on the dynamics of economic and ethnic segregation, migration, urban policy, and neighbourhood effects.

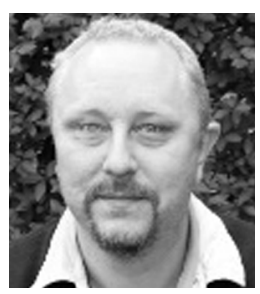

John Östh is a Professor in Human Geography at Uppsala University and leader of the Calista research group. His research is oriented towards GIS and spatial analysis with a particular interest in questions related to human mobility, accessibility, and urban analytics. John has developed spatial analytics software (EquiPop) and methods for studying spatial interaction and mobility-decay using register data and Big data repositories. John is currently administrating the research databases PLACE and MIND at Uppsala University. 